\title{
Occupying the Fringes: The Struggles of Women in Artisanal and Small-Scale Gold Mining in Rural Ghana-Evidence from the Prestea-Huni Valley Municipality
}

\author{
Francis Arthur-Holmes ${ }^{1}$ (D) Kwaku Abrefa Busia ${ }^{2}$
}

Published online: 15 June 2020

(c) The Author(s) 2020

\begin{abstract}
Across many mineral-rich developing countries, artisanal and small-scale mining (ASM) has been noted as a crucial socio-economic activity for most rural people. Over the past 2 decades, there has been growing participation of women in the ASM sector with extant studies examining why women participate in ASM, the roles they play and how their involvement enhances their socio-economic development. However, the socio-structural dynamics and gendered relations within ASM are poorly understood and underexplored despite the increasing participation of women in the sector. Based on field observations and interviews involving 49 women miners in the Prestea-Huni Valley Municipality of Ghana, this paper discusses the on-site challenges of women in ASM through multiple standpoint and African feminism theoretical perspectives. It also examines how understanding the struggles of women can reduce their work-related risks and promote gender-sensitive policies for rural women's empowerment in ASM. The study finds that the struggles of working women in ASM involve cultural marginalisation and gendered work patterns, poor working environment, poor work support services for women with children, lack of legal and economic rights, and inter-ethnic discrimination by employers. We argue that policymakers, relevant stakeholders, and the government through the district assemblies should collaborate with small-scale mining employers to enhance gender-sensitive on-site regulatory policies, ensure safe working environments for workers, and provide locally appropriate work support services for women in ASM. We further argue that, government and regulatory institutions need to promote gender mainstreaming for 'inclusion of women' in the management structure at mine sites and also the extraction and processing stages of ASM.
\end{abstract}

Keywords Artisanal and small-scale mining (ASM) $\cdot$ Rural women $\cdot$ Gendered relations $\cdot$ On-site challenges $\cdot$ Cultural marginalisation $\cdot$ Ghana

Francis Arthur-Holmes

frarthur88@gmail.com

Extended author information available on the last page of the article 


\section{Abbreviations}

ASM Artisanal and small-scale mining

SSA Sub-Saharan Africa

PBMA Prestea-Bondaye Mining Area

PHM Prestea-Huni Valley Municipality

CUREC Central University Research Ethics Committee

NHIS National Health Insurance Scheme

\section{Introduction}

Artisanal and small-scale mining (ASM) remains an important source of employment and income for many rural communities across the developing world [27]. In particular, ASM has become an alternative livelihood strategy for many rural dwellers who are unabsorbed by the formal sector $[28,53]$ and also as a relatively stable lucrative employment outside the subsistence and seasonal agricultural sector $[31,32]$. ASM has been noted as a poverty-driven economic activity involving the extraction and processing of minerals through labour-intensive techniques and rudimentary equipment [1]. However, it is pertinent to note that the ASM sector has seen a relatively higher level of sophistication in some developing countries. In Ghana, for instance, since the influx of Chinese gold miners from the early 2000s, the ASM industry has been transformed by imported sophisticated machines [5], popularly known as Chang fa. Since the 1980s and 1990s, structural adjustment programs in many mineral-rich developing economies had profound effects on ASM participation and its regulations due to the push from trade and farming activities by many impoverished people to the ASM industry [47]. Many people, both skilled and unskilled, had to diversify their livelihood sources to engage in ASM activities, further expanding the scale of the informal ASM sector. According to the International Labour Organisation [32], an estimated 13 million people are directly involved in ASM globally, with an additional 100 million people depending on the sector for their livelihoods. Out of this number, women account for $50 \%$ of this labour force [32], with the highest percentage of women in ASM being 50\% in Africa, $10 \%$ to $20 \%$ in Latin America and $10 \%$ in Asia [31]. According to McQuilken and Hilson [36], Ghana's ASM industry employs about 1 million people and supports approximately 4.5 million others, with women representing $50 \%$ of the workforce.

Until fairly recently, women's role in ASM received little attention, mainly due to the dominant recognition of mining operations as a male activity [35, 47] despite the increasing participation of women. As Susapu and Crispin [46] assert, women are seldom recognised as 'miners', although some partake in digging, sluicing and separation of gold and burning of amalgam. Hinton et al. [31] further emphasised the dearth of studies concerning women's participation in ASM as a significant knowledge gap in the literature. Over time, various studies have investigated reasons for women's involvement in ASM across various developing economies, particularly sub-Saharan Africa (SSA) [4, 53], the impacts of ASM on women's living conditions $[8,29]$, the direct and indirect roles performed by women in the ASM sector $[31,33,46]$, the localised and internationalised drivers of women into ASM [32, 47] 
and how formalisation processes in the ASM industry across the developing world consider women's socio-economic development [13].

In the Ghanaian context, extant studies on the nexus between women and the largely informalised ASM sector have been expanding. Recent studies have focused on the historical trajectories of mining [30, 40], causes of female participation in ASM [4, 53], work patterns, discrimination, and gender reproduction [11, 33] and the impact of ASM on the livelihoods of women in Ghana [8, 53]. However, previous studies have not adequately investigated the risks and challenges women artisanal miners encounter in their work domain. As Buss et al. [9] point out, "very little is known about the operations of gender norms, structures and relations concerning women's livelihoods in ASM zones'. Studying the difficulties of women in ASM is crucial for addressing their persistent 'stay-behind' roles that increase their economic marginalisation and socio-cultural invisibility in the sector as well as pushing for gender mainstreaming in ASM. This paper, therefore, provides a detailed analysis of women's struggles in ASM in the Prestea-Huni Valley Municipality of the Western Region of Ghana. It emphasises the socio-cultural structures and actions that perpetuate gender inequalities in ASM. As Koomson [33] highlights, women's unequal access to the benefits of the ASM industry is as a result of social organisation that normalises gender ideologies and values and consequently reproduces gender inequalities. This paper, therefore, contributes to the growing literature on women's involvement in ASM in Ghana and Africa, and more precisely, their onsite struggles and experiences in the male-dominated mining industry.

The paper is organised into five sections. After this introductory section, the next section provides a theoretical framework of gender inequality through a 'standpoint' perspective [23, 25] and African feminism theory [39]. Through a multiple standpoint and African feminism framework, the paper contributes to the understanding of the shared and varied perspectives of rural African women miners' plights at their workplace. The third section involves the research methodology followed by the research findings and discussion. The last section provides a conclusion which discusses the policy implications based on the findings of the study.

\section{Theorising from the Stories of Women in ASM: Multiple Feminist Standpoint Theory and African Feminism}

Standpoint theory frames the notion that based on one's socially lived experiences, their perspective on social phenomena may differ with where they stand. According to Harding [22], a standpoint refers to an identification of 'a morally and scientifically preferable grounding for the interpretation and explanation of nature and social life'. As Pilcher and Whelehan [42] emphasise, standpoint theorists in gender studies argue that understanding of the world is related to gendered social positions and social groups. As such, the social position of women is relevant for studying the gendered relations, working patterns and discrimination against women as well as the intra-gender discourses and experiences among women in the maledominated mining industry. According to Hartsock [25], feminist researchers have not fully considered the epistemological consequences of their claim concerning 
the structural differentiation between men and women's lived realities. This situation, according to standpoint theorists, foregrounds the need for research-generated knowledge as an important critique of traditional scientific epistemologies [22, 44]. To this end, the gap in knowledge concerning gendered structures and relations as well as women's working conditions in ASM speaks to the gender mainstreaming concerns in the sector. Standpoint theory, therefore, supports what Sandra Harding refers to as 'strong objectivity' which emphasises the notion that the perspectives of marginalised and oppressed people (in this case women in ASM) can help create more objective accounts and relevant knowledge of the social world [23]. Hence, people's situated, everyday experiences should serve as an entry point of investigation [44]. As Rouse [43] further argues, knowledge claims and their justification form part of understanding the world and that knowledge develops from specific circumstances with real consequences which have a causal relationship. Owing to this assertion, Rouse maintains that knowledge has both (socio) political and epistemic importance regarding which concepts are deemed intelligible, which reasons are understood to be relevant and forceful and which conclusions are credible [43]. From this viewpoint, standpoint theory 'gives a voice' to marginalised groups to challenge the existing inequalities in society as the outsider within based on the liberatory potential and the achieved character of knowledge through a standpoint [25].

Standpoint theory or feminist standpoint theory has its roots from a Marxist theoretical perspective [42, 51]. Notably, Hartsock [25] argued that a feminist standpoint could be developed from Marx's argument of knowledge structured by location in material (or economic) life and Lukács' idea of the 'standpoint of the proletariat' [42]. Again, Hartsock's feminist standpoint derives from Friedrich Hegel's study of different standpoints between slaves and masters in 1807 [51]. According to Wood [51], Hegel argued that the master-slave relationship highlights an individual's social position and how social groups affect people's knowledge and power relations. Postcolonial critics of Hegel's master-slave dialectics argue that while the slave in Hegelian terms gains self-consciousness and freedom through labour, the colonial slave seeks freedom not only through labour but to 'become like their master' in order to reverse the structural inequality [15]. It is on this basis that Hartsock examines the gendered relations between men and women in society using the experiences of women as a knowledge source and a basis for addressing gender inequality. Thus, while the standpoint of Marx focused on class and capitalism, Hegel on masters and slaves, and Fanon on the coloniser and colonised, Hartsock's feminist standpoint looked into sex and gender issues.

Researching into women's lives illuminates the totality of the social order and 'their world of work', particularly in working environments like mining perceived as male-oriented. As evident in Koomson's study of gender and small-scale gold mining in Northern Ghana, the sector encouraged gender-specific tasks with women performing aboveground work and men engaging in the more productive underground work at the Tallensi mine [33]. Men's underground work is considered more productive because it requires high labour-intensive physicality and technology, which are seen to be better adapted to physicality and relative strength of men. Thus, activities like working in underground mines, digging, using explosives to blast rock surfaces, and processing mineralised sands are reserved exclusively for men since they are 
deemed to constitute the integral part of the mining process. In contrast, women's upper ground jobs such as carrying mineralised sand from the extraction sites to the processing sites, are often underrated as secondary roles, and requiring less labour intensity compared to men's roles. These roles are usually enhanced by unwritten socio-cultural customs and traditions that dictate women's role and access to benefits in ASM due to the prevailing discriminatory labour dynamics and structured gendered hierarchies. This gendered order re-echoes Elson and Pearson's assertion that workers' conditions in the labour market cannot merely be studied in terms of national and class struggle alone but also from a gender struggle perspective [14].

In expanding her feminist standpoint theory, Hartsock identifies certain key features concerning her theoretical argument. These essential elements are that: (a) material (economic) life structures understanding and knowledge; (b) those groups occupying different positions in the economic structure will have different 'worldviews'; (c) the power of the dominant group means that their perspective is hegemonic; (d) as a consequence, the 'vision of the oppressed' must be struggled for [25]. The standpoint approach for this study examines the struggles of women in ASM not only based on women's disproportionate access to the benefits of the ASM sector due to their lower socio-economic position but also the differences among women in the sector rather than a single 'women's experience'. As such, it recognises multiple standpoints of women artisanal miners, including married women, single women, women with young children, migrant women and native women engaged in ASM. This emphasis addresses the essentialist standpoint feminism idea of a universal 'women's experience', thereby failing to capture women's diverse lived realities across time and space [42]. As Hartsock [26] later admits, her early focus on 'women' was simplified due to the omission of other important social relations, hence the need to adopt multiple standpoints. From this contemporary relational standpoint, women's experiences should not be viewed as uniform for merely being 'women' but also considering their diverse individual experiences with other women and also with men in society which altogether create the existing social inequalities. These multicultural and postcolonial perspectives on standpoint feminism resist mainstream feminism's tendency to universalise women's experiences of oppression and struggles without considering the crucial differences across national, ethnic, racial, and religious backgrounds that embrace womanhood [19, 37, 39].

Given the different experiences and perspectives of women miners in rural Ghana, an African feminist standpoint theory also provides a useful framework to understand their struggles in relation to other women and also with men. The experiences of rural Ghanaian women are shaped by a complex tapestry of historical and cultural eventualities that reflect the unique social context through which their informal work in ASM takes place. As Goredema [19] points out, African women's inequality is structured differently due to the accumulation of different political, socio-economic, and cultural experiences in society and the historical oppression of women's identities. The struggles of Ghanaian women in ASM, as African women who live and work within a culturally scripted male hegemony and its colonial and postcolonial influences, highlight the 'masculinity' features attached to mining in Africa throughout history. It is to this extent that ASM is generally reserved for men in the face of discriminatory cultural customs and practices, patriarchy, inadequate 
capital and credit facilities and lack of gender-sensitive legal and regulatory frameworks that serve as barriers to women's engagement in ASM. African feminism, therefore, argues for the inclusion and validation of the multiple experiences and diverse backgrounds of African women in the mainstream feminism discourse [19]. In some African cultures, women are strictly prevented from working inside underground mining pits, mine shafts, owning mine sites and in some cases engaging in ASM without experiencing name-calling and family disapprovals [31-33]. These socio-cultural dynamics, therefore, make it very problematic for women to be recognised within the ASM sector, let alone their work and contribution, which is highly underestimated. Women's role in ASM remains at the fringes due to gendered roles where women only play supporting roles such as carrying loads, sorting, and washing minerals and processing the waste. Worse off, these roles are highly dependent on the demand at the mine sites, especially in underground ASM, which sometimes relies on the sympathy of male employers to get women miners to carry mineralised sand to processing sites for meagre incomes.

Through an African feminist standpoint, which is rooted in the on-site experiences of rural Ghanaian women in ASM, their oppression, cultural marginalisation, injustice, treatment as second-class workers at mine sites and ethnic discrimination can be analysed and better understood from their 'own' perspectives. As Nkealah asserts, African feminism is firmly rooted in the 'lived' experiences and realities of continental African women as opposed to African women in the diaspora and western women [39]. Defying the socio-cultural norms to engage in ASM, Ghanaian women have to endure working in mining environments which are generally unfriendly to women and children with little or no work support services. Moreover, women miners in ASM are also faced with constant threats of termination and replacement, hardly benefit from limited social safety nets, lack economic and legal rights, and experience ethnic-related favouritism which make them dependent on male employers from similar backgrounds at ASM sites to ensure timely wages. These experiences highlight a 'unique perspective' on the social world through the lens of women miners in Ghana. Thus, postcolonial and multicultural feminism reconfigures contemporary philosophy by putting crucial factors such as class, race, and ethnicity at the centre of the feminist agenda alongside the traditional issues of feminist philosophy such as mainstream philosophies of experience and Enlightenment-based notions of modernity, progress, and rationality, without falling into the trap of 'cultural essentialism' [37, 38].

From a multiple feminist standpoint approach and African feminism, knowledge should be understood as situated, specific and local to the social position of its producers (rural women in ASM) [19, 39, 45]. Drawing from these theoretical insights on (multiple) standpoint theory and African feminism, this paper tries to understand and provide knowledge of women's struggles in the ASM sector in rural mining communities in the Prestea-Huni Valley Municipality of Ghana. Given that standpoint theory was more theory-based since its origins, this study offers an empirical contribution to the study of women as a marginalised social group (bearing in mind their multiple standpoints) in the male-dominated ASM industry in a non-western context and more specifically, Ghana. In this study, it is recognised that women's 'worldviews' and participation in ASM have mainly been overlooked, consequently relegating the crucial roles women play in ASM and the challenges they face to 


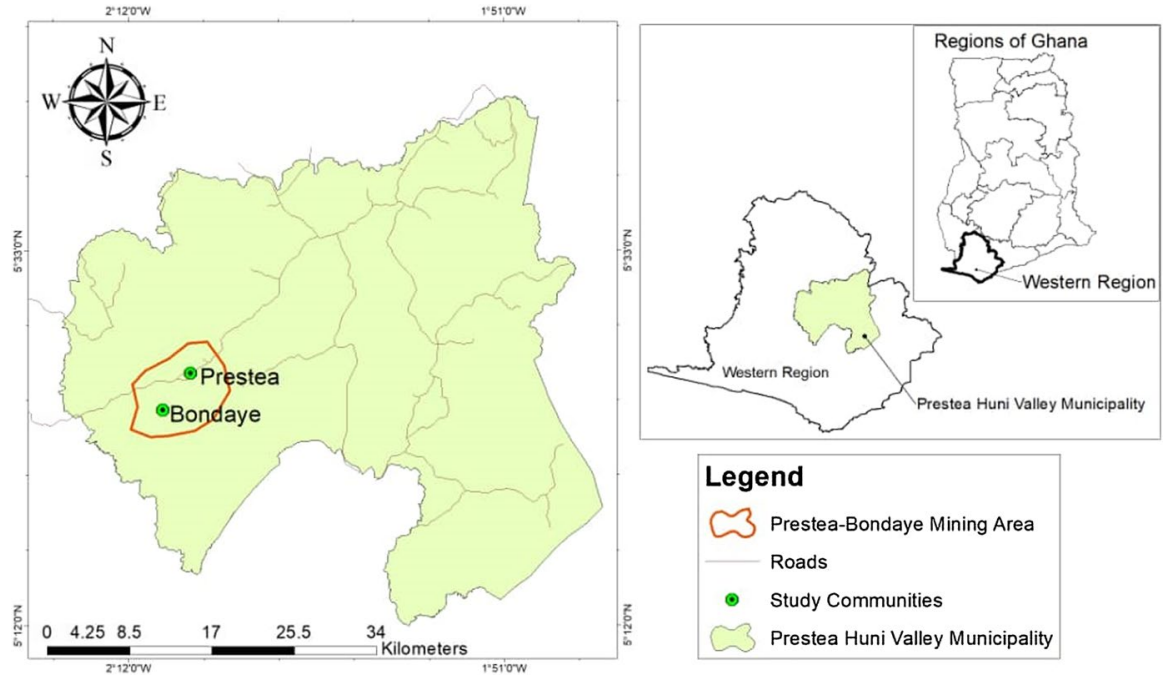

Fig. 1 Maps showing the study area Source: Authors' construct of Prestea-Huni Valley Municipality, Ghana, based on ESRI Shapefiles using ArcGIS 10.6

the background. The struggles and fringe locations of women in the ASM working environment would, therefore, be explored to illuminate the multiple standpoints of women as well as their Afrocentric experiences as rural ASM workers in the empirical sections of this paper.

\section{Research Setting and Methodology}

\section{Study Site}

This study is part of a broader research on bargaining power and power relations of women in ASM conducted between July 3 and September 10, 2017, in the Prestea-Bondaye Mining Area (PBMA) in the Prestea-Huni Valley Municipality of the Western Region of Ghana. The study was to assess how women miners bargain for power and also how their roles at the mining sites facilitated gendered relations. Prestea-Huni Valley Municipal became a district in 2008 until 2017 when it was elevated to a municipality. The Prestea/Bondaye mining communities are located in Southwest Ghana and cover about $50 \mathrm{~km}$ north of the coast of the Atlantic Ocean [18](See Fig. 1). Settlement in the area which dates back to over a hundred years ago was primarily due to the discovery of gold thus culminating in various mining activities. Again, the Prestea-Huni Valley Municipality (PHM) has a land area of $1809 \mathrm{~km}^{2}$ and constitutes $7 \%$ of the total land coverage of the Western Region of Ghana (See Fig. 1). The study area, Prestea/Bondaye, lies on the west bank of the Ankobra River, which is used for 'illegal' ASM activities, locally referred to as galamsey [18]. The municipality boasts of a tremendous natural geographic advantage of resource endowment in terms of minerals and forest resources. The 
municipality falls within the forest-dissected plateau physiographic region, which is made up of Precambrian rocks of Birimian origin noted for gold formation and subsequently ASM activities in the region [41]. Prestea and Bondaye communities were selected for the study mainly because of their heterogeneous nature in terms of ethnic groups and having a significant number of women engaged in ASM. Concerning women's involvement in ASM at PBMA, a pilot survey at the mine sites in 2017 showed that approximately 3000 women participated in ASM. This socio-cultural heterogeneity offers the opportunity to investigate the diverse struggles and experiences of women in the ASM sector and their relational standpoint to men at the mining sites. Besides, the study area has a wet equatorial climate found in the rain forest zone of Ghana with a mean annual rainfall of about $187.83 \mathrm{~mm}$ [18]. This high rainfall occurrence impacts ASM activities in the municipality due to the potential interruptions and increased occupational hazards.

\section{Sampling and Research Participants}

As the broader study employed a qualitative approach investigating gender relations and power dynamics in the ASM sector, women who were directly engaged in ASM in the selected mining communities in the PHM were selected to respond to the interview guide. The diversity of women miners interviewed included married women, single women, women with young children and babies, native women, and migrant women of varying ages in the PBMA. The kind of jobs the women miners engaged in were primarily carrying mineralised sand in pans and sometimes providing water for washing mineralised sand. Purposive and convenience sampling techniques were employed for the research. Convenience sampling technique was used to select female miners for interviews because of the availability of many women at the mining sites and their willingness to partake in the research after their consent was sought. Initially, 82 women were informed of this particular topic regarding their struggles in ASM and briefed about the purpose and nature of the study. Out of the 82, 49 women verbally consented to be interviewed and were subsequently recruited for the study. Purposive sampling proved useful for selecting women miners because it aims to obtain access to participants who are knowledgeable about the topic under investigation [10, 34].

\section{Research Instruments, Data Collection Procedure and Ethical Considerations}

Qualitative interviews and observations were employed to collect empirical data for the study. In-depth interviews using a semi-structured interview guide were used to obtain relevant information on the struggles of women in ASM. From a standpoint approach, the use of in-depth interviews was to gain deeper insights from women's own accounts and experiences of their on-site work challenges and struggles. Also, participant observation played a crucial role in obtaining the nuances of the struggles of women artisanal miners as they went about their working activities. The reason for employing participant observation to discover the activities and struggles of women in ASM was to obtain much in-depth information from "unsolicited accounts" [21]. Eight (8) sites in 10 days were visited purposely to observe how 
women performed their tasks and also concerning the struggles they go through at the mining sites. The interviews ended with a follow-up question which allowed the interviewees to raise important questions that were not covered [6].

Before the main data collection started, a pilot study was conducted from July 4 to July 13,2017 , to check the validity and reliability of the research instruments as well as the appropriateness of the questions for the research. Forty-nine (49) women miners, 22 and 27 from Prestea and Bondaye respectively, were interviewed. The interviews were mostly done in Wassa and Fante. ${ }^{1}$ Where the interviewees did not understand and could not speak Wassa or Fante, other participants from similar ethnic backgrounds of such interviewees volunteered to translate it to their native language. These volunteers were duly informed concerning helping the first researcher understand the various languages of the migrant female miners and assured of their confidentiality and anonymity. Later, the translated responses which were recorded were checked with some known migrant community members to ensure that certain meanings were not lost in translation. However, all responses were written in English to ensure content validity. On average, each semi-structured interview took about $40 \mathrm{~min}$. An hour was allocated to each of the 49 interviewees to voice their struggles. However, depending on the availability of time, especially during breaks while working and after work in the afternoons, some interview sessions were either short of an hour or exceeded the allocated time.

The research was approved by the Central University Research Ethics Committee (CUREC) through the Oxford Department of International Development with reference number, CUREC 1A/ODID C1A 17-032. Informed consent which involved disclosing the purpose of the research to the study participants and the possible risks of their participation in the study was done $[10,34]$. Permission was obtained from interviewees to record interviews and take notes before interviews. Again, permission and consent were also sought from mine employers and some women miners concerning the capture and dissemination of photographs, especially those involving children at the sites. A considerable number of interviewees were not comfortable signing the written informed consent forms. Hence, oral consent was adopted. Interviewees were free to opt out of the interview at any time. Four (4) women opted out of the interviews because they were very tired and could not continue with the interview. Interviewees were assured of the confidentiality of their responses and their personal experiences of engaging in ASM during the field interviews.

\section{Data Analysis}

Data analysis was done in two phases: during and after the data collection period. Short interviews were listened to and transcribed during the data collection period. Phenomena observed at the sites were written down in a notebook. After the entire data collection, all other audio-recorded interviews were played back, transcribed, and written into English. Handwritten notes were read for overall understanding and identification of predominant patterns and arguments. This was purposely done

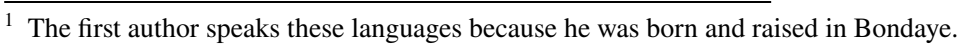


to remove any inconsistencies of the notes in the field book. Apart from this, the main themes in the interview transcripts were written down and inductively analysed. Thematic content analysis technique was, therefore, used to identify recurring themes within the data and issues which were considered in relation to the objective of the study. Both the data analysed during and after the data collection period were juxtaposed together and then grouped into related themes and concepts. This revealed the contradictions and similarities of the research findings under investigation. In the end, thematic analysis proved useful for making interesting and nuanced arguments with the relevant literature situated within ASM.

\section{Findings and Discussion}

\section{Cultural Marginalisation and Gendered Labour Dynamics}

A striking feature of the ASM industry across many developing countries is the gendered norms that structure ASM activities. The study found that women miners in the Prestea-Bondaye mining communities faced numerous forms of cultural marginalisation which kept them at the less productive 'margins' of the industry. In particular, cultural customs, superstitious beliefs and social taboos encouraged this gendered order which translated into women miners engaging in lower-level supporting roles compared to managerial roles and ultimately ownership of mine sites. In the PBMA, women's work at the mining sites primarily involved carrying mineralised sand in pans and sometimes providing water to wash the mineralised sand. Thus, women were rarely seen inside the mine shafts and underground mine pits where extraction occurred. The extractive activities at the sites which involved digging, use of hand tools and mineral processing were reserved for men following local cultural customs and taboos that barred women from working in the underground pits unless the mineral sand was brought to the surface. For instance, a woman at Bondaye indicated that:

Most people, especially the men working at this site, have the belief that gold mining is associated with cleanliness. As such, anything which is unclean is seen as an impediment to its discovery. It is something we came to meet, and as such, we are treated as unclean, particularly during our menstrual periods. That is why we are prevented from working in the underground pits and some other mining sites where these beliefs are strictly followed (28-year native woman).

This explanation highlights the socio-cultural customs and perceptions about women that create and sustain the gender struggles of women miners in the sector. Such role definitions based on socio-cultural norms, beliefs, and practices, therefore, determined what roles women performed at the mining sites rather than based on their efforts and skills. In some mining sites in the PBMA, women were barred from working there mainly due to the perceived notions of 'uncleanliness' during their menstrual period. A similar study by Ofosu-Mensah [40] also found that women were prohibited from visiting some mining sites in Adanse in Ghana to engage in 
gold mining when undergoing their menses. Given this situation, the cultural marginalisation of women in mining activities due to the perception of 'uncleanliness' at mining sites provided a structural basis where men had power over women concerning which roles to be done, what tools to use, access to mine sites and how much women earned. As emphasised by Koomson [33], 'normative social-cultural values, symbolic representation, and meaning-making influence gender roles and practices, which reproduce gender inequities over time. As such, from an African feminist perspective, the ideological framework rooted in cultural customs and traditional beliefs at the mines perpetuate a gendered order where women's work is confined to supporting and subsidiary roles which are usually underpaid and treated as casual. Consequently, this working environment attaches a low premium to women's labour in ASM in addition to widespread discriminatory practices. Women miners, therefore, experienced multiple inequalities at ASM sites due to entrenched gendered norms and taboos that structure the kind of activities available to women and their involvement in ASM [9]. From a standpoint viewpoint, it can be argued that the power of the dominant group (men) in the ASM sector implies that their perspective is hegemonic [26] and translates into the social reality where the marginalisation and vulnerability of women miners and their work roles become 'normalised'.

Another important aspect of women's marginalisation in ASM at the Prestea/ Bondaye mining sites concerned how site committee membership disfavoured women. In most of the mining sites, committees were usually formed to evaluate all activities, prevent casualties and to also make crucial decisions on their illegal (galamsey) activities. It was generally reported by most women that male miners perceived them as not having adequate knowledge and skills about mining activities to be included in the committees. This implied that women were not involved in the decision-making and management roles at the ASM sites. As explained by this woman:

We have committee members here at this site which includes prominent local people in the community. However, they hardly involve some of us women. Some of the male miners are of the view that we lack skills, confidence, and courage to settle seemingly complex disputes at the mining sites. On one occasion, for instance, a male committee member inquired, 'can women settle misunderstandings involving men?', as if we lack abilities to resolve disputes. Some of them can be my children, and I settle incidences of similar conflicts in the community, so it is unfortunate why they think we cannot manage disputes here when there are issues (42-year native woman, Prestea).

This explanation supports the assertion by Buss [9] in their studies in Central and East Africa that 'gender inequality is a structural condition of ASM'. It further emphasises how gender norms and the informal organisational structure of ASM puts women in a disadvantaged position regarding their involvement in the management and day-to-day running of these sites. As such, women had no place in the decision-making and consultation committees but only mattered as labourers. This finding aligns with Dreschler's [12] study in Tanzania and Brotten and Ba's [7] study in Mali, which found women at the bottom of the hierarchical structure of ASM. Women in ASM, therefore, have to negotiate and re-negotiate their access 
and upward mobility [47] due to the entrenched socio-cultural norms which worsen women's socio-economic outcomes in SSA.

\section{Poor Working Environment and Risk of Occupational Hazards}

Due to the mostly 'illegal' nature of ASM activities in many sub-Saharan African countries, including Ghana, the industry is often characterised by poor working environments which put workers at various environmental and health-related risks. As Hentschel, Hruschka and Priester [27] emphasise, ASM is regarded as dirty, unregulated, dangerous, and environmentally degrading and characterised by poor working environment. Because of women's increasing involvement in ASM activities, it was important to investigate the environmental, health and safety working conditions of women miners through a standpoint lens. As earlier emphasised in this paper, the climate of the Prestea-Huni Valley Municipality is associated with high rainfall patterns. As such, the weather conditions in the area made it difficult for both women and men to work, particularly during the rainy season. From field observations, the ground became muddy and slippery when it rained, causing some women to slip and fell with their loads. In some observed instances, some women sustained injuries and cuts by sharp rock outcrop at their feet when they fell. In order to avoid such accidents and injuries, many women miners removed their sandals or shoes and walked barefooted at the mining sites, especially when the slippery effect increased with the amount of rainfall. As these women lamented:

When it rains, we still carry loads unless it rains heavily. We are here today, and you can see we are carrying loads instead of halting the job and continue [sic] when the rains stop. Just look at the woman over there [pointing fingers] who fell, I think she needs someone to help her stand up. The owners are all after money, so most do not care even if it is raining. They will just say if you cannot carry loads in the rain, stop and go home. It is difficult to work during the rainy season because our lives are at risk, and there is no safety for us (26year migrant woman, Prestea).

As you can see, there are no comfortable shelters for us here, especially when it rains. The men in charge of the site do not care much about our working conditions. There are only a few tents here to accommodate us [women] and other male workers. Because of this, we often use our head pans to cover our heads while standing in the rain. This is very bad for us, but what can you do (34-year migrant woman, Bondaye).

The sentiments of the women artisanal miners demonstrated the problematic working conditions of women in small-scale gold mining at the sites, particularly when it rained. It was observed that the few tents available at the galamsey sites were used for food vending and for protecting mining machines which were used for smoothening mineralised sand materials (see Fig. 2). As a result, the tents could not cater for one-fourth of all male and female miners, totalling about six hundred people at the sites. Because a few tents were mounted to protect the machines, men who operated the machines had some minimal shelter during rains 


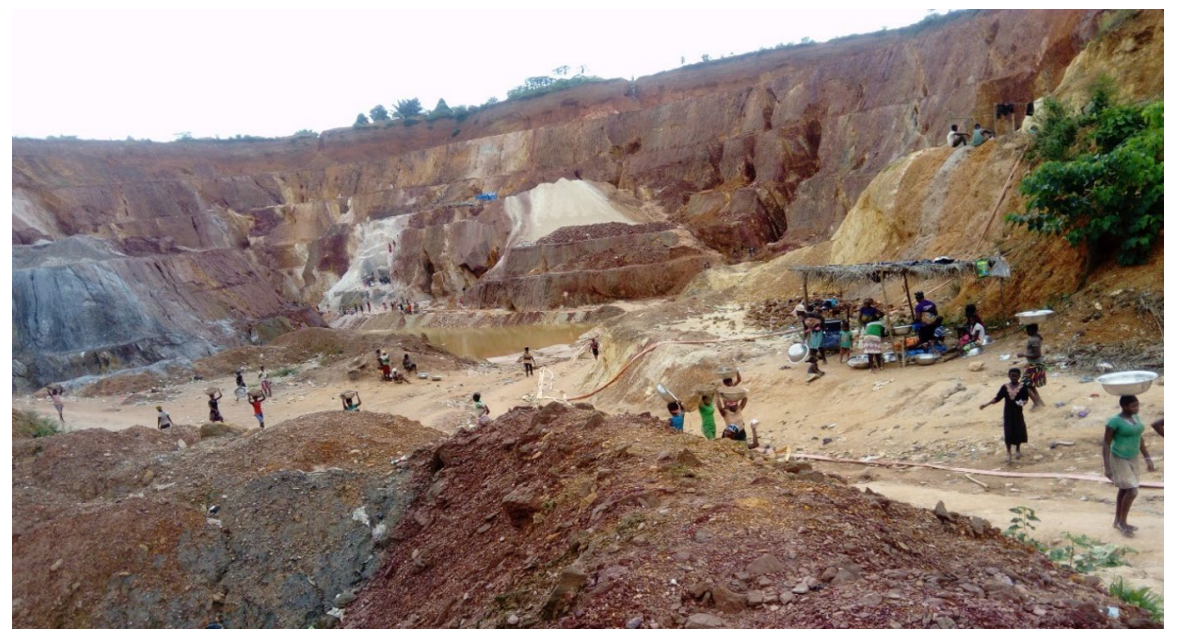

Fig. 2 Tent(s) used by vendors and self-proclaimed galamsey owners

at the expense of most of the women miners. This partly supports extant research in the ASM sector which highlights gender disparities in exposure to environmental and health hazards as important factors [3, 31]. As Armah et al. [3] assert, gender differences in exposure to risk factors and psychology as well as sexrelated factors and varying social situations produce gender-specific occupational health problems.

Besides, the rains were observed to slow down women's activities at the sites. Women miners who could not carry the loads in the rains had to stop and go home. Only a few women had umbrellas to use during the rains with most of them shivering while going about their work. Most of the mine owners present at the time of the rain did not stop the women from carrying the loads with the justification that they needed more mineralised sand for sluicing. On the part of women working in the rains, they indicated that they needed to work in order to get enough money to take care of their families, even though their health was at risk. As Hartsock [24] reminds us, groups that occupy different 'social locations' in the economic structure will have different 'worldviews' based on their standpoints. As such, while the mine owners were interested in getting more mineralised sand even while raining, women miners who continued working also considered the vulnerability of themselves and their families as a justification, despite the risky and unsafe working environment during the rains. The effect of the rains on women's activities in ASM explains the vulnerability context of the sustainable livelihood framework where seasonality in the form of rainfall affects people's livelihoods and their incomes. It is to this end that the World Health Organisation emphasises fair employment and decent work while advocating for fair minimum wages, full employment and occupational health and safety standards [52]. Moreover, the severe conditions of women in ASM underscore the need for a particular emphasis on educational and gender issues as well as opportunities in the sector $[50,53]$. 


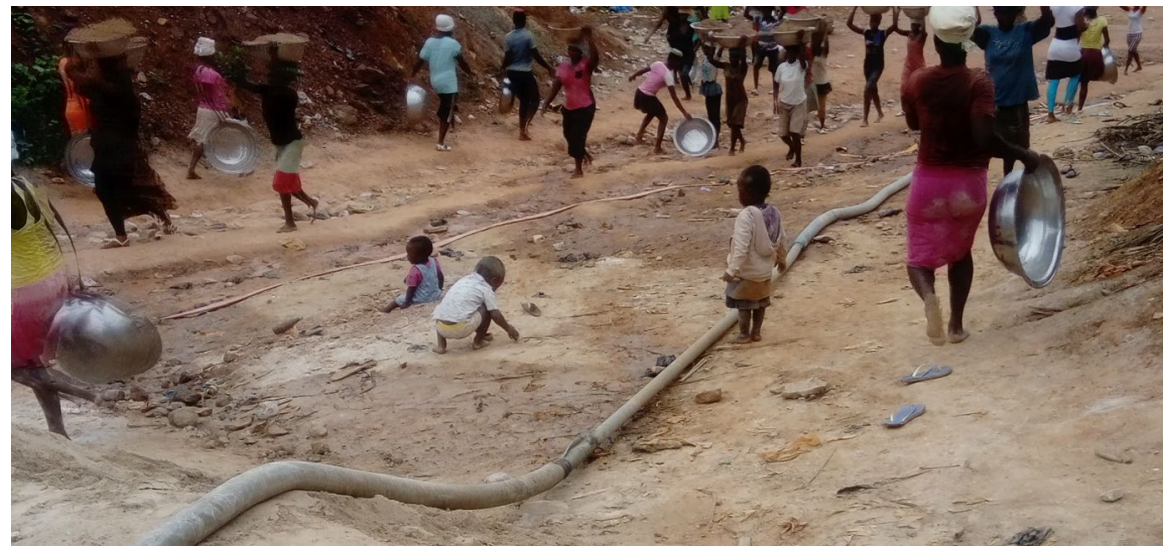

Fig. 3 Children left at the sites without any attention given to them

\section{Poor On-site Work Support Services}

Another critical struggle women miners with babies and children had to contend with is the poor on-site support services at the mine sites. Women who brought their babies and children to the galamsey sites had to give their little children and sometimes babies to food vendors to care for them and in some instances leaving children under tents (with or without anyone's care). From the field observations, many of the little children were roaming and playing at the sites with no proper supervision (see Fig. 3). This exposed them to many health risks and physical injuries as they were bumped into by adult women miners who sometimes poured their loads on them. Most women indicated that they had difficulties in their work as a result of the lack of facilities by the mine owners to cater for their children on-site. These women expressed their concerns:

I have to come to the mining site with my baby because I do not have someone to take care of her in the house. Other women here carry loads with their babies too because they prefer that to leaving them under the tents for the watchman [security guard] who may not have time to look after them. For me, I cannot leave my baby for someone, although it is not easy to do so considering the health risk associated with carrying loads with my baby. If I have other work to do, I will stop this galamsey activity. I always have headaches, back and waist pains. Although some owners promised to help those of us with babies in order to perform our task of carrying loads without the babies' interruption, we are yet to see it become a reality. Sometimes, while I am carrying the loads with my baby and she cries, it presents me with a difficult situation whether to stop or continue with it. In such instances, I have to dump the loads at the processing area before I can attend to her. Since we work for the Chang fa owners [mine employers], they should 


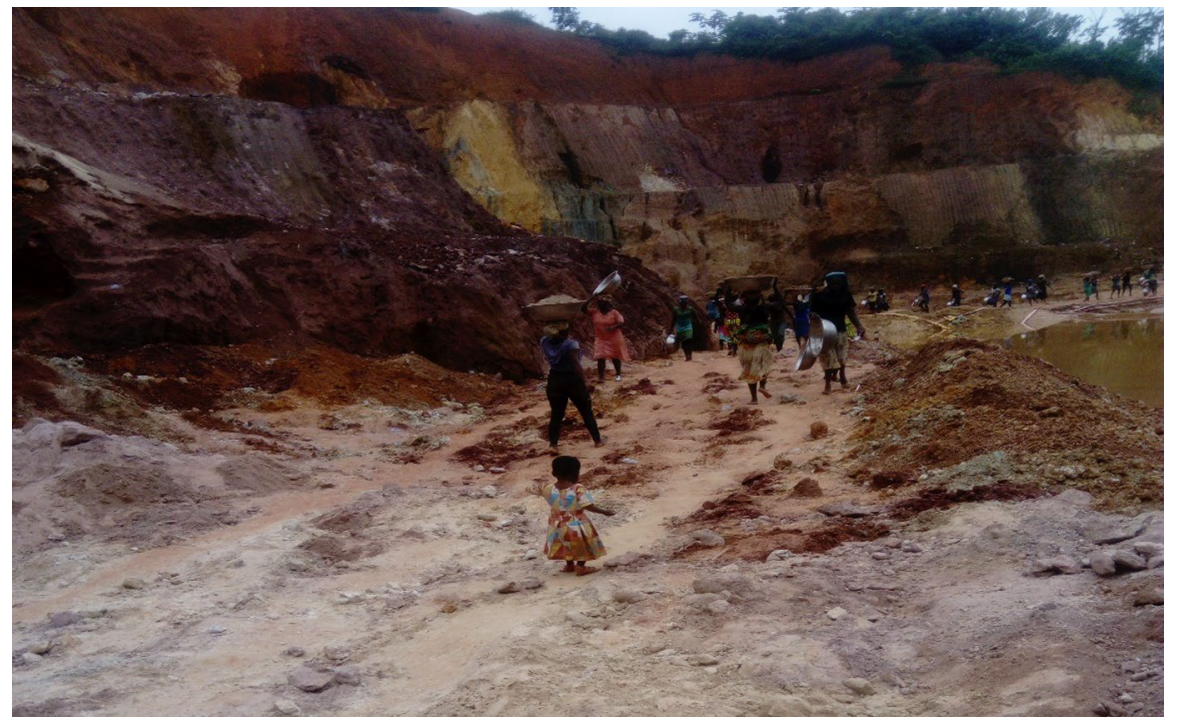

Fig. 4 A little girl following her mother while crying at a mining site

employ nannies at the site and build a proper structure for them to look after our kids (33-year migrant woman, Prestea).

In order for the work to progress well, the owners should consider our welfare and babies as well as the conditions we go through here. You know they are nothing without our efforts and activities, yet they treat us like beggars or just labourers because we are poor and need money to survive. All I ask of the owners is that they consider the struggles we go through at this site and if we were their wives or sisters, would they treat us as beggars? Our babies are important to us if we are nothing to them (29-year migrant woman, Bondaye).

The accounts of women with children at the sites highlight gender-insensitive facilities for babies and children at the sites. This situation compounded women's work responsibilities as some mothers had to stop their work from time to time to attend to their children or babies, consequently slowing the pace of work and prolonging the time they used to finish their work. At times, children followed their mothers while crying (see Fig. 4). Concerning this, it was reported by some of the women that a child below 3 years had fallen into an open pit filled with water and died. As a result, those with babies and children complained bitterly that the site committee members and galamsey owners had not devised any mechanism to monitor their children and babies at the sites. For such women with babies and children, having to work with their babies at their back and also taking breaks as and when necessary, hindered their work. However, as they relied on ASM for their basic and family needs, having to combine work and caring for the babies and children on-site worsened their day-to-day struggles, especially in the absence of work support services at the mining sites. 
Furthermore, another concern of most women miners during the field interviews was the poor health care support available to them. For many women interviewed, the health risks of carrying heavy loads of mineralised sand made them expose to various health-related problems such as waist pains, (severe) headaches, back and foot pain. Due to the physical nature of galamsey, most women usually get tired after a day's work. As Grzywacz, Almeida, Neupert and Ettner [20] emphasise, less-educated workers (in ASM activities) are very likely to experience psychosocial stress at work. That notwithstanding, there is no health support for women miners who become ill and need (special) treatment.

Concerning the lack of healthcare support, some women mentioned that:

Even when we are sick, the Chang fa owners do not support us with money to buy drugs. We will even be grateful if they register the national health insurance scheme for us so that we can use it when we are sick. I remember working with one Chang fa owner. He told me that if I was sick, I should stay in the house and not come and disturb him with sickness problem (33-year migrant woman, Prestea).

I am seriously sick. But, I have not received any support from my two employers. I told them about my condition, and they promised to assist me with some funds. Till now, I have not heard from them. Even if they cannot help me, they should pay my medical bills because it is through the carrying of loads that caused this sickness (40-year native woman, Bondaye).

The issue of health-related support for women at the sites also shows how the struggles of women without children on-site differed from mothers who came to the site with babies from a 'standpoint' perspective. However, the general concern for gender-sensitive facilities for caring for children and babies and also for health benefits from their employers was shared by many female miners. It was revealed during the interviews, that many women worked with different owners which made it challenging to enrol them onto the National Health Insurance Scheme (NHIS). Ghana's NHIS is a public social intervention scheme established in 2003 by the government to provide quality healthcare for residents of Ghana. Subscribers for the scheme fall under two main categories: the informal and exempt groups. For the informal group subscribers, under which the women miners can be identified, they are expected to pay a premium in addition to the registration and renewal fees before accessing healthcare through the NHIS. However, as the accounts of the interviewees demonstrate, women miners are treated as casual, easily replaceable labour whose work is highly devalued in the mining operations as primarily 'load carriers'. As such, this categorisation of women's labour in ASM highlighted the lack of preparedness of informal ASM employers to support the women working on their sites in processing their NHIS registration to access healthcare. Moreover, the unwillingness of employers to provide health-related benefits to the women miners was also due to the multiple employers the women worked with. This situation complicated the responsibility of which employer ought to enrol the women miners on the NHIS, especially when the employers knew the women worked at other mine sites. In some few instances, women who got injured during work were provided with first aid and had to bore the cost of their treatment. This finding supports Gabel et al. [16] 
assertion that less-educated workers in low-wage employment are less likely to have health-related benefits such as paid sick and personal leave, workplace wellness programs and employer-sponsored health insurance.

\section{Lack of Legal and Economic Rights of Women Miners}

Another important struggle of women miners in ASM at the Prestea/Bondaye mining sites was their lack of legal and economic rights. In some instances, women were not paid for their work due to their 'marginalised roles' regarding carrying mineralised sand and other gendered low-level roles. For most women, their main concern was not so much to do with the low grade mineralised sand they carried at the sites, but rather working without being paid. To this end, women lacked legal and economic rights in the ASM sector, thereby making it difficult to take legal action to demand their hard-earned wages. Compounded by the illegal nature of their ASM operations in Ghana and the antagonism of the general public against galamsey workers, there is very little institutional support from the government and non-governmental institutions to address these concerns of women miners. Although Ghanaian labour laws provide legal protection for women and casual workers, women in ASM are unable to pursue formal justice for unfair treatment at their workplaces, mainly because the informal, unregistered environments within which they work are deemed illegal under the Ghanaian ASM laws. As explained by these women:

For one month now, I have not been paid because they [employers] said they had no money to pay me and others. How can I survive if I am not paid? I still come to the site to carry loads. What the owner said was that the grade of mineralised sand we carried was low, so he did not give us money for that. But to me, this is not fair. I need to borrow to survive as this work we do is 'from hand to mouth'. Even when the owners decide to pay us what they owe for previous work, they discriminate (35-year native woman, Bondaye).

Once I was sick and needed money very urgently. Meanwhile, I was owed by one of my employers for the previous month and asked for it. He tossed me around for some time and later paid me for my work after putting pressure on him. After paying me, he told me in my face that, he would get someone to replace. Replace me for demanding what I was due, can you imagine? Yet we have no one to listen to the problems we face here (33-year migrant woman, Prestea).

During interview sessions, women miners lamented as to why various institutions could not help them when their wages were not paid by their employers. Despite admitting the unlicensed and illegal aspects of their work, most women miners complained about being neglected by various stakeholders in the mining industry. The statements by these women miners highlight the inadequacy of a gendered perspective on existing legal and regulatory mechanisms surrounding ASM in Ghana. For instance, despite being the first sub-Saharan African country to pass laws regulating ASM in 1989 (PNDCL 218), this legal framework focused mainly on the technical, administrative, and marketing aspects of ASM [17]. Consequently, the structural 
dynamics within ASM and the growing involvement of women in the sector have received minimal legal and regulatory considerations. Currently, Ghana's principal laws on mining, namely the Minerals and Mining Act, 2006 (Act 703) (as amended by the Minerals and Mining Act, 2015 (Act 900) and the Minerals Commission Act, 1993 (Act 450) primarily highlight the state ownership of minerals in their natural state, licensing regulations, mineral rights and the statutory powers of the regulatory institutions. Where subordinate legislation to the principal law in the form of legislative instruments exist, they tend to focus on compensation and settlement, licensing, general regulations, mining support services, explosives regulation as well as health, safety, and technical regulations. Thus, there is no explicit attention to gender mainstreaming in mining in general, and ASM in particular, thereby disregarding women's economic rights and worsening their poverty levels and other vulnerabilities.

Women miners were generally treated as easily replaceable workers and as a result, often underpaid, had wages delayed or in extreme cases unpaid. Due to the highly undervalued nature of women's work in ASM, they are often underpaid and hardly ever benefit from limited state social safety net programs, regardless of the registration status of the mine [48]. When women's wages were not paid, responses from the women miners indicated how difficult it was for them to provide food for their families as most of them relied on the earnings from their ASM activities. Because of this, women's wages become very crucial for the status of their children since they tend to spend their earnings directly on their children's needs [49]. However, the poor state of gender-sensitive mining legislations and the unregistered operations at PBMA contributed to women's inability to take formal legal action against their employers when they were not paid coupled with the constant threats of termination and replacement by their employers. Thus, the 'illegality' of ASM at the mine sites at PBMA further worsened the struggles of women miners with respect to their legal and economic rights.

\section{Inter-ethnic Discrimination and Multiple Representations}

Linked to the lack of women's legal and economic rights in ASM, a few women emphasised discriminatory practices by their employers, particularly concerning their wages. This was indicated both in terms of outstanding wages and actual wages. For instance, when outstanding wages were being settled, some women miners based on their ethnic associations and relationships with the owners were either paid at the expense of others or paid earlier than other women. This situation usually generated quarrels and misunderstanding between galamsey owners and the women miners who were not paid. As this woman clarifies:

My owner has his favourites, and these people are his friends and people who belong to his ethnic group. Sometimes it is not the same ethnic group but their neighbours. I have not been paid for the previous month, but I know some are paid. Some of us are not happy about this situation. Anytime I complain about this situation, the owner I am working with tells me it is not true. Some women quarrel with their owners over unpaid wages. Those who are North- 
erners $^{2}$ mostly get favours from their fellow people functioning as Chang $\mathrm{fa}$ owners. Because most of the women who carry the loads at this site are Northerners, (we) the few $\mathrm{Akan}^{3}$ people struggle to get some favours. In some sites, Akans also get favours in terms of paying arrears, some receive it early and others later or not all (35-year native woman, Bondaye).

Such ethnic discriminatory practices and favouritism by employers at the sites disadvantaged some women who felt 'used' and sidelined. This favouritism occurred as a result of the prevalent yet subdued ethnic tensions between the ethnic minorities of the North and the predominantly Akan communities of the South, particularly within the context of migrant Northerners who work in the mining communities in Southern Ghana. Thus, where employers were natives, the wages of women miners from the native communities were usually paid before migrant women. Sometimes, this was done to check the influx of migrant women dominating local women in ASM activities. Similarly, where migrant Northerners employed women miners, they also favoured women from the North and often discriminated against Southerners concerning wages. From an African feminist perspective, the statements by the women miners show that African women's struggles are not only framed from the perspective of their gender but also identities interlocked with ethnic, class and sometimes religious affiliations. As such, there are multiple expressions of women's struggles within ASM - from women with or without children on-site, as well as young and old women who are all living through the socially, economically and ethnically stratified environment of ASM. The multiple representations of women in ASM partly feed into the favouritism by employers towards women from their ethnic backgrounds.

From a multiple standpoint lens, it also becomes evident that women's experiences of discrimination were very different depending on the relations with male employers and their ethnic backgrounds. As such, contemporary standpoint theory's emphasis on 'relational standpoint' provides a nuanced understanding of women's standpoint in ASM rather than the earlier notion of a universalised women's experience. To this end, this finding supports Andermahr, Lovel and Wolkowitz [2] argument that people [women] are both oppressed in some situations and relative to some people while equally privileged in some other situations. Consequently, the ethnic displays of favouritism by some male employers towards women from their ethnic groups such as paying them earlier than others made the women subservient and heavily reliant on their ethnic-affiliated employers in order to ensure their wages were not delayed. This was particularly evident among women working at underground ASM sites where they were primarily responsible for transporting mineralised sand to the processing sites after the men had brought the mineralised sand to the surface. Thus, the devalued roles of women as mere 'carriers' in underground ASM sometimes depended on the sympathy of male miners to give them

\footnotetext{
${ }^{2}$ Referring to ethnic groups in Northern Ghana such as the Kusasi, Dagomba, Frafra who serve as migrant workers in various ASM sites in Southern Ghana.

${ }^{3}$ The largest ethnic grouping in Ghana, from which the Wassa, Fante and other native ethnics in the Prestea/Bondaye mining communities come from.
} 
something to do. It is to this end that, African feminism broadly hinges on the idea of gender inclusion, collaboration, and accommodation to ensure that both women and men contribute (even if not equally) to improving the material conditions of women [39]. As evident from the accounts of some women miners, being on good terms with male employers of similar ethnicity becomes somewhat important for receiving timely wages. Accordingly, the ethnic discriminations highlighted by these women miners emphasise how ethnic favouritism reinforces the dependence of women on men within their ethnic group (and not the importance of their own labour) for things they are entitled to, such as fair pay and respect for their dignity and humanity.

\section{Conclusion and Policy Implications}

This study investigated how women in artisanal and small-scale gold mining in the Prestea-Huni Valley Municipality struggle in the historically male-dominated industry. The standpoints of women were discussed concerning their gendered roles in ASM relative to men and how their experiences in their work activities were structured by various socio-structural norms. The study highlighted five main struggles of female miners that limit their productive capacities and empowerment in the sector. These struggles included various forms of cultural marginalisation that rested on social norms, beliefs and cultural practices that prevented women from accessing mining sites or working in the profitable roles in ASM. This situation encouraged gender inequities and thus entrenching gendered work patterns. Other struggles of women included poor working environments, poor on-site work support services and facilities, especially for working mothers and lack of legal and economic rights. This study emphasised the on-site maternal struggles of working women with children in ASM sites which are mostly unexplored regarding the nexus of gender and ASM. The last struggle of women this study identified was inter-ethnic discrimination of women miners by their employers which provided interesting perspectives on the multiple standpoints of women rather than a uniform experience of their struggles, despite some shared common experiences. This paper has, therefore, highlighted the on-site challenges and diverse experiences of women miners in ASM. The novelty of the paper lies with how the work is grounded within the multiple standpoint framework - practically demonstrating the shared and different plights, struggles, and varying negotiation abilities of rural women on-site to access income in ASM in Ghana. Furthermore, the paper has also engaged with African feminism from the perspectives of rural Ghanaian women engaged in ASM and their linkages to postcolonial and multicultural perspectives on multiple standpoint feminism.

The findings of this study are critical for policy considerations, in that while recent studies on women in ASM suggest a potential impact on improving women's living conditions when adequately empowered, it is very crucial also to consider the risks and challenges women face in the sector. This consideration helps to understand and reduce women's work-related struggles and promote gender mainstreaming in ASM. Due to the inadequacy of gendered regulations in ASM and the male-dominated nature of ASM operations, women's on-site struggles in the sector 
have been sidelined. This is particularly relevant as the 'illegality' of ASM in Ghana worsens the struggles of women in areas such as accessing formal legal and economic rights and work support services. Thus, local government authorities in the mining communities should be empowered to collaborate with mine employers and relevant traditional institutions to address the struggles of women miners. That way, they can adequately monitor their operations, health and environmental standards as well as address discriminatory practices against women. To this end, the new Community Mining Program launched in July 2019 by the Ghanaian state to allow local government structures regularise ASM and promote sustainable mining practices needs to effectively consider and enforce gender-sensitive policies in the sector.

Funding The author(s) disclosed receipt of the following financial support for the research. This work was supported by the Oxford Department of International Development (ODID) and St Antony's College, University of Oxford through departmental fieldwork award and STAR Grant award respectively. The sponsors, however, played no role in the study design, data collection and data analysis, manuscript preparation, and publication of this article. This research formed part of the first author's (FA-H) MPhil dissertation under the supervision of Dr Cheryl Doss at ODID.

\section{Compliance with Ethical Standards}

Conflict of interest The authors declare that they have no conflict of interest.

Ethical Approval Since the research involved human participants, ethical approval was provided by the Central University Research Ethics Committee (CUREC), Oxford University, through the Department of International Development with reference number, CUREC 1A/ODID C1A 17-032.

Open Access This article is licensed under a Creative Commons Attribution 4.0 International License, which permits use, sharing, adaptation, distribution and reproduction in any medium or format, as long as you give appropriate credit to the original author(s) and the source, provide a link to the Creative Commons licence, and indicate if changes were made. The images or other third party material in this article are included in the article's Creative Commons licence, unless indicated otherwise in a credit line to the material. If material is not included in the article's Creative Commons licence and your intended use is not permitted by statutory regulation or exceeds the permitted use, you will need to obtain permission directly from the copyright holder. To view a copy of this licence, visit http://creativecommons.org/licen ses/by/4.0/.

\section{References}

1. Afriyie, K., Ganle, K. J., \& Adomako, A. A. J. (2016). The good in evil: A discourse analysis of the galamsey industry in Ghana. Oxford Development Studies, 44, 493-508.

2. Andermahr, S., Lovel, T., \& Wolkowitz, C. (1997). A concise glossary of feminist theory. London: Arnold.

3. Armah, F. A., Boamah, S. A., Quansah, R., Obiri, S., \& Luginaah, I. (2016). Working conditions of male and female artisanal and small-scale goldminers in Ghana: Examining existing disparities. Extractive Industries and Society, 3(2), 464-474.

4. Arthur, F., Agyemang-Duah, W., Gyasi, R. M., Yeboah, J. Y., \& Otieku, E. (2016). Nexus between artisanal and small-scale gold mining and livelihood in Prestea Mining Region, Ghana. Geography Journal, 2016, 1-18.

5. Boafo, J., Paalo, S. A., \& Dotsey, S. (2019). Illicit Chinese small-scale mining in Ghana: Beyond institutional weakness? Sustainability, 11, 1-18. 
6. Braun, V., \& Clarke, V. (2013). Successful qualitative research: A practical guide for beginners. London: Sage.

7. Brottem, L. V., \& Ba, L. (2019). Gendered livelihoods and land tenure: The case of artisanal gold miners in Mali, West Africa. Geoforum, 105, 54-62.

8. Buor, D., \& Ayim, G. (2019). Women in artisanal and small-scale mining in the Adansi North District, Ghana. Global Journal of Human-Social Science: B, 19(3), 22-31.

9. Buss, D., Rutherford, B., Hinton, J., Stewart, J., Lebert, J., \& Cote, G. E., et al. (2017). Gender and artisanal and small-scale mining in Central and East Africa: Barriers and benefits (Working Paper GWP No. 2017-2). Ottawa.

10. Denscombe, M. (2007). The good research guide: For small-scale social research projects (3rd ed.). Maidenhead: Open University Press.

11. Dinye, R. D., \& Erdiaw-Kwasie, M. O. (2012). Gender and labour force inequality in small-scale gold mining in Ghana. International Journal of Sociology and Anthropology, 4(10), 285-295.

12. Dreschler, B. (2001). Small-scale mining and sustainable development within SADC Region. London.

13. Eftimie, A., Katherine, H., Strongman, J., Hinton, J., Lahiri-Dutt, K., \& Mutemeri, N. (2012). Gender dimensions of artisanal and small-scale mining. A rapid assessment toolkit. Washington, DC: World Bank.

14. Elson, D., \& Pearson, R. (1981). Nimble fingers make cheap workers: An analysis of women's employment in third world export manufacturing. Feminist Review, 7(1), 87-107.

15. Frantz, F. (1967). Black skin, white masks. New York: Grove.

16. Gabel, J., Levitt, L., Holve, E., Pickreign, J., Whitmore, H., Dhont, K., et al. (2002). Job-based health benefits in 2002: some important trends. Health Affairs, 21(5), 143-151.

17. Ghana Government. (1989). Small scale gold mining Law. PNDCL 218. Ghana Government: Ghana.

18. Ghana Statistical Service. (2014). Population and housing census, 2010 analytical report. Accra, Ghana: Prestea-Huni Valley District.

19. Goredema, R. (2010). African feminism: The African woman's struggle for identity. African Yearbook of Rhetoric, 1(1), 33-41.

20. Grzywacz, J. G., Almeida, D. M., Neupert, S. D., \& Ettner, S. L. (2004). Socio-economic status and health: A micro-level analysis of exposure and vulnerability to daily stressors. Journal of Health and Social Behaviour, 45(1), 1-16.

21. Hammersley, M., \& Atkinson, P. (2007). Oral accounts and the role of interviewing. In M. Hammersley \& P. Atkinson (Eds.), Ethnography: Principles in practice (3rd ed., pp. 97-120). London: Routledge.

22. Harding, S. (1986). The science question in feminism. Milton Keynes: Open University Press.

23. Harding, S. (1993). Rethinking standpoint epistemology: What is strong objectivity? In L. Alcoff \& E. Potter (Eds.), Feminist epistemologies (pp. 49-82). New York: Routledge.

24. Hartsock, N. (1983). Money, sex and power: Toward a feminist historical materialism. Boston: Northeastern University Press.

25. Hartsock, N. (1997). Comment on Hekman's truth and method: Feminist standpoint theory revisited. Signs, 22(2), 367-374.

26. Hartsock, N. (1998). The Feminist Standpoint Revisited and Other Essay. Oxford: Westview Press.

27. Hentschel, T., Hruschka, F., \& Priester, M. (2002). Global report on artisanal and small-scale mining. London: Country Study commissioned by MMSD.

28. Hentschel, T., Hruschka, F., \& Priester, M. (2003). Artisanal and small-scale mining challenges and opportunities. London: International Institute for Environment and Development. https://doi. org/10.1007/978-0-387-93958-2.

29. Hilson, G. (2002). Small-scale mining and its socio-economic impact in developing countries. Natural Resources Forum, 26(1), 3-13.

30. Hilson, G. (2002). Harvesting mineral riches: 1000 years of gold mining in Ghana. Resources Policy, 28(1-2), 13-26.

31. Hinton, J. J., Veiga, M. M., \& Beinhoff, C. (2003). Women and artisanal mining: Gender roles and the road ahead. In G. Hilson (Ed.), The socio-economic impacts of artisanal and small-scale mining in developing countries. Leiden: Swets Publishers.

32. International Labour Organisation. (1999). Social and labour issues in small-scale mines. Report for discussion at the tripartite meeting on social and labour issues in small-scale mines. Geneva: International Labour Organisation. 
33. Koomson, E. (2018). Work patterns and gender reproduction in the Talensi small-scale gold-mining industry in Ghana: Implications for social welfare policy. International Journal of Social Welfare, 28(1), 100-107.

34. Kvale, S. (1996). Interviews: An introduction to qualitative research interviewing. London: Sage.

35. Labonne, B. (2014). Who is afraid of small scale and artisanal mining (ASM)? Extractive Industries and Society, 1(2), 121-123.

36. McQuilken, J., \& Hilson, G. (2016). Artisanal and small-scale gold mining in Ghana. Evidence to inform an 'action dialogue'. IIED. London. https://doi.org/10.13140/RG.2.2.36435.99368

37. Narayan, U. (1998). Essence of culture and a sense of history: A feminist critique of cultural essentialism. Hypatia, 13(2), 86-106.

38. Narayan, U., \& Harding, S. (Eds.). (2000). Decentering the center: Philosophy for a multicultural, postcolonial, and feminist world. Bloomington: Indiana University Press.

39. Nkealah, N. (2016). (West) African feminisms and their challenges. Journal of Literary Studies, $32(2), 61-74$.

40. Ofosu-Mensah, E. A. (2010). Traditional gold mining in Adanse. Nordic Journal of African Studies, 19(2), 124-147.

41. PHDA (Prestea-Huni Valley District Assembly). (2010). Prestea-Huni Valley assembly medium term development plan (2010-2014). Prestea: PHDA.

42. Pilcher, J., \& Whelehan, I. (2004). Fifty key concepts in gender studies. London: Sage Publications. https://doi.org/10.5860/choice.42-1270.

43. Rouse, J. (2009). Standpoint Theories Reconsidered. Hypatia, 24(4), 200-209.

44. Smith, D. (2005). Institutional Ethnography: A Sociology for People. Toronto: AltaMira Press.

45. Stanley, L., \& Wise, S. (1993). Breaking out again (2nd ed.). London: Routledge.

46. Susapu, B., \& Crispin, G. (2001). Report on small-scale mining in Papua New Guinea. London: Country Study commissioned by MMSD.

47. Tallichet, S. E., Redlin, M. M., \& Harris, R. P. (2006). What's a woman to do? Globalised gender inequality in small-scale mining. In G. Hilson (Ed.), The socioeconomic impacts of artisanal and small-scale and small-scale mining in developing countries (pp. 205-219). London: Taylor \& Francis.

48. Traore, P. A. (1994). Constraints on small-scale mining in Africa. Natural Resources Forum, 18, 207-212.

49. United Nations Childrens' Fund. (1999). Women in transition. Italy: Florence.

50. Veiga, M. M., Maxson, P. A., \& Hylander, L. D. (2006). Origin and consumption of mercury in small-scale gold mining. Journal of Cleaner Production, 14(3), 436-447.

51. Wood, J. T. (2008). Critical feminist theories. In L. A. Baxter \& D. O. Braithwaite (Eds.), Engaging theories in interpersonal communication: Multiple perspectives (pp. 323-334). Thousand Oaks, CA: Sage.

52. World Health Organisation. (2009). Closing the gap in a generation: Health equity through action on the social determinants of health. Geneva: World Health Organisation. https://doi.org/10.1016/j. respe.2009.04.006

53. Yakovleva, N. (2007). Perspectives on female participation in artisanal and small-scale mining: A case study of Birim North District of Ghana. Resources Policy, 32(1-2), 29-41.

Publisher's Note Springer Nature remains neutral with regard to jurisdictional claims in published maps and institutional affiliations. 


\section{Affiliations}

\section{Francis Arthur-Holmes ${ }^{1}\left[\right.$ [ Kwaku Abrefa Busia ${ }^{2}$}

Kwaku Abrefa Busia

kwakuabrefabusia@ln.hk

1 Oxford Department of International Development, University of Oxford, 3 Mansfield Road, Oxford OX1 3TB, UK

2 Department of Sociology and Social Policy, Lingnan University, Dorothy Y. L. Wong Building, Tuen Mun, New Territories, Hong Kong 